\title{
Capital Controls and Monetary Policy Autonomy in a Small Open Economy
}

Davis, J. Scott, Ignacio Presno

Davis, J. Scott, Ignacio Presno (2017). Capital Controls and

Monetary Policy Autonomy in a Small Open Economy.

International Finance Discussion Papers 1190.

https://doi.org/10.17016/IFDP.2017.1190

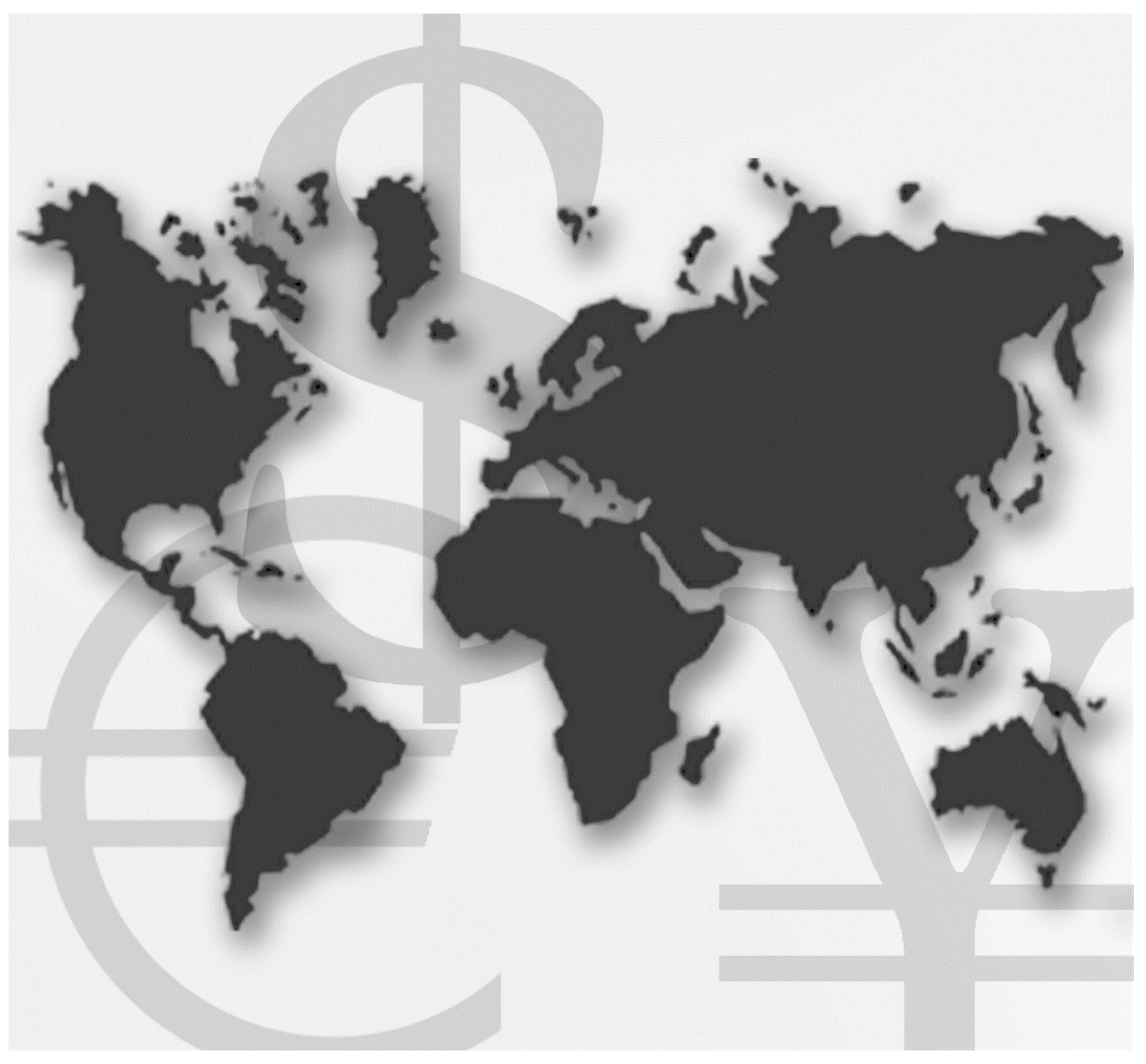

\section{International Finance Discussion Papers}

Board of Governors of the Federal Reserve System

Number 1190

February 2017 
Board of Governors of the Federal Reserve System

International Finance Discussion Papers

Number 1190

February 2017

\title{
Capital Controls and Monetary Policy Autonomy in a Small Open Economy
}

\author{
J. Scott Davis \\ Ignacio Presno
}

NOTE: International Finance Discussion Papers are preliminary materials circulated to stimulate discussion and critical comment. References to International Finance Discussion Papers (other than an acknowledgment that the writer has had access to unpublished material) should be cleared with the author or authors. Recent IFDPs are available on the Web at www.federalreserve.gov/pubs/ifdp/. This paper can be downloaded without charge from the Social Science Research Network electronic library at www.ssrn.com. 


\title{
Capital Controls and Monetary Policy
}

\section{Autonomy in a Small Open Economy}

\author{
J. Scott Davis* \\ Ignacio Presno \\ Federal Reserve Bank of Dallas Federal Reserve Board of Governors
}

January 2017

\begin{abstract}
Is there a link between capital controls and monetary policy autonomy in a country with a floating currency? Shocks to capital flows into a small open economy lead to volatility in asset prices and credit supply. To lessen the impact of capital flows on financial instability, a central bank finds it optimal to use the domestic interest rate to "manage" the capital account. Capital account restrictions affect the behavior of optimal monetary policy following shocks to the foreign interest rate. Capital controls allow optimal monetary policy to focus less on the foreign interest rate and more on domestic variables.
\end{abstract}

Keywords: capital controls; credit constraints; small open economy JEL Classification: F32; F41; E52; E32

*This paper previously circulated under the title "Capital Controls as an Instrument of Monetary Policy". We would like to thank seminar participants at the Reserve Bank of New Zealand and participants at the Carnegie-Rochester-NYU conference, the HKIMR-BoG-ECB-FRBD conference on "Diverging monetary policies, global capital flows, and financial stability", the 2015 meeting of the Society for Economic Dynamics in Warsaw and the 2014 Dynare conference in Paris for many helpful comments and suggestions. We would also like to thank Gianluca Benigno, Javier Bianchi, Martin Bodenstein, Luca Dedola, Mick Devereux, Fabio Ghironi, Kevin Huang, Matteo Iacoviello, Gianni Lombardo, Anna Orlik, Fabrizio Perri, and Albert Queralto. The views presented here are those of the authors and should not be interpreted as reflecting the views of the Federal Reserve Bank of Dallas, the Board of Governors of the Federal Reserve System, or any other person associated with the Federal Reserve System.

${ }^{\dagger}$ Federal Reserve Bank of Dallas, 2200 N. Pearl Street, Dallas, TX 75201, USA Email: scott.davis@dal.frb.org

${ }^{\ddagger}$ Federal Reserve Board, 1801 K Street, Washington D.C. 20036, USA Email: ignacio.presno@frb.gov 


\section{Introduction}

Repeated cycles of capital flows into and out of emerging markets are a fixture of the financially integrated global economy. Surges in capital inflows have led to talk of "currency wars" and the danger of overheating in many emerging markets. Likewise, a sudden reversal of capital flows has been blamed for the recent financial and macroeconomic instability in many emerging markets.

Rey (2015) and Forbes and Warnock (2012) show that capital flows into and out of emerging markets are largely driven by global factors. Reinhart and Reinhart (2009) argue that surges in capital inflows into emerging markets are associated with a higher likelihood of banking, inflation, and currency crises, and contribute to economic and financial instability. Kaminsky et al. (2005) argue that capital inflows are a primary reason for the procyclicality of monetary policy observed in many emerging markets. Rey (2015) argues that this cycle of capital inflows and outflows means that the "trilemma" of international finance is actually more of a "dilemma", and that "independent monetary policies are possible if and only if the capital account is managed." Obstfeld (2015) addresses this same issue and acknowledges that under certain conditions, a central bank with a floating currency has complete monetary autonomy, but he discusses how financial globalization affects the trade-offs faced by monetary policy makers. ${ }^{1}$

In this paper we address this issue in a dynamic, general equilibrium model where nominal rigidities and credit frictions give rise to welfare reducing distortions. A policy maker sets policy in order to minimize the effects of these distortions. If there are multiple distortions and only one monetary policy instrument then the policy maker is faced with a trade-off. How are these trade-offs in a small open economy affected by exogenous shocks from the rest of the world that lead to sharp reversals in capital inflows and outflows? How will capital

\footnotetext{
${ }^{1}$ The trilemma has been a feature of the international macroeconomics literature since Mundell (1963). The trilemma states that a country cannot simultaneously maintain a fixed exchange rate, an open capital account, and monetary policy autonomy.

In technical terms, the fact that the combination of a fixed exchange rate and an open capital account lead to the loss of monetary policy autonomy is purely mechanical. When a central bank maintains a fixed exchange rate, monetary policy takes the form of a rule stating that the nominal exchange rate is held constant. So for instance, in response to a fall in net capital inflows, the central bank is forced to raise the interest rate to attract capital flows and prevent depreciation.
} 
account restrictions affect the trade-offs that the policy maker faces? What implications does this have for the losses due to certain frictions in the economy?

This paper shows that a central bank with a flexible exchange rate may find it optimal to use its interest rate instrument to "manage" the capital account (i.e. stabilize capital flows). When borrowers are subject to collateral constraints, changes in capital inflows and outflows can lead to financial instability. When the amount that individuals can borrow depends on the value of existing collateral at the current market price, a fall in net capital inflows following a foreign shock can push down asset prices and tighten the collateral constraint in the small open economy, leading to a credit crunch. In this case, the central bank of the small open economy will find it optimal to raise the interest rate in order to attract net capital inflows, even though the foreign shock is leading to a fall in output.

Given this finding, we then show how the use of capital controls can free the interest rate from this need to manage the capital account. Similar to how the use of capital controls allows greater monetary policy autonomy in a country with a fixed exchange rate, we show how the use of capital controls allows greater monetary policy autonomy in a country with a flexible exchange rate.

To frame the discussion we begin by presenting some empirical evidence of this channel. In regressions similar to those in Shambaugh (2004), Obstfeld et al. (2005), and Klein and Shambaugh (2015), we show that imposing capital account restrictions leads to a significant increase in monetary policy autonomy. This empirical finding is true not only for countries with a pegged currency, where this gain in autonomy is mechanical, but for countries with a floating currency as well.

Then, in a DSGE model with both price and credit frictions, we compute optimal monetary policy in a small open economy following an exogenous shock to the foreign interest rate under different levels of capital account openness. The model is solved with a piecewise linear approximation to a non-linear solution, and thus takes account for potential asymmetries that may arise from potentially non-binding collateral constraints. We show how the use of capital controls significantly affects the degree of monetary policy autonomy and allows the central bank to use its monetary policy instrument for domestic stabilization. Finally 
we consider the welfare implications of the use of capital controls. Capital controls are not costless and reduce the ability of agents in the small open economy to borrow and lend on international markets to smooth consumption, but by limiting the distortionary effects of fluctuations in capital flows, capital controls can result in a net welfare gain.

A number of recent papers have addressed the issue of how capital controls can be used to minimize the effects of distortions arising from financial frictions. Korinek (2010), Jeanne and Korinek (2010), Bianchi (2011), Benigno et al. (2013), Korinek (2013), and Bianchi and Mendoza (2015) all discuss how the fact that collateral constraints depend on either asset prices or non-traded good prices, which are subject to fluctuations from capital inflows, leads to under- or over-borrowing and financial instability. Specifically the inefficient level of borrowing is caused by a pecuniary externality, where agents don't internalize the effect that their collective actions are having on asset or non-traded good prices and thus collateral constraints. They discuss how counter-cyclical taxes on capital inflows and other macroprudential measures can be used to offset this externality and reduce financial vulnerabilities. Brunnermeier and Sannikov (2015) and Heathcote and Perri (2016) discuss how capital controls can enhance international risk sharing. Engel (2015) surveys the recent literature on capital controls and macroprudential policy in a world of volatile international capital flows and discusses how capital controls can be used as a macroprudential regulation to correct for certain financial distortions.

However, while the aforementioned papers consider the effect of distortions arising from financial frictions or limited international risk sharing, the models exhibit flexible prices and do not have a role for conventional monetary policy. Schmitt-Grohe and Uribe (2012b), Schmitt-Grohe and Uribe (2012a) and Farhi and Werning (2012) show how counter-cyclical capital controls policy can play a role in macroeconomic stabilization in a small open economy with a fixed exchange rate, but in these models, conventional monetary policy is dedicated to maintaining a fixed exchange rate, and capital controls frees monetary policy from the constraints of the trilemma. ${ }^{2}$ Our paper will consider the case where monetary policy can be

\footnotetext{
${ }^{2}$ In addition, some recent papers, like Costinot et al. (2011) and De Paoli and Lipinska (2013), Heathcote and Perri (2016), and Farhi and Werning (2014) discuss the optimal use of capital controls for terms-of-trade manipulation as a way to improve welfare in an open economy.
} 
set freely. Aoki et al. (2016) consider the welfare effects of various permanent and temporary macroprudential polices, including capital controls, in a small open economy subject to world interest rate shocks where domestic monetary policy is dedicated to price stability. They find that capital controls lead to a significant welfare improvement when monetary policy is dedicated to domestic stabilization. While not the same, this is similar in spirit to the main findings of this paper, that capital controls allow optimal monetary policy to focus more on domestic stabilization and less on managing the external accounts.

This paper will proceed as follows. Some simple empirical results that frame our discussion are presented in section 2. The theoretical model used to derive the optimal policy results is described in section 3 . The calibration of the model and the solution procedure are discussed in section 4 and the results are presented in section 5 . Finally section 6 concludes.

\section{Empirical Evidence of Capital Controls and Mone-}

\section{tary Policy Autonomy}

We begin by estimating a simple monetary policy rule in a small open economy. Assume that the central bank in country $j$ sets its nominal interest rate with the following Taylor rule:

$$
i_{j t}=\bar{\imath}_{j}+\theta_{p}\left(\pi_{j t}-\bar{\pi}_{j}\right)+\theta_{y}\left(y_{j t}-\bar{y}_{j t}\right)+\theta_{s}\left(i_{t}^{*}-\bar{\imath}^{*}\right)+m_{t}
$$

where $i_{j t}$ is the nominal interest rate in country $j, \bar{\imath}_{j}$ is the neutral or steady state value of this interest rate, $\pi_{j t}$ is the inflation rate, $y_{j t}$ is $\log$ GDP, $\bar{\pi}_{j}$ is the inflation target, $\bar{y}_{j t}$ is $\log$ potential output, and $m_{t}$ is a monetary shock. The interest rate $i_{t}^{*}$ is the "base" country interest rate, the interest rate in the rest of the world, and $\bar{\imath}^{*}$ is the neutral or steady state value of this interest rate. For most countries and most years in this panel data, the base country interest rate is the U.S. Fed Funds rate, but for some countries and some years, the base country interest rate is the interest rate on the British pound or the euro. The data for this empirical exercise is taken from Klein and Shambaugh (2015). See the appendix to this paper for the complete list of countries and their corresponding "base" country. 
Take the first difference of this Taylor rule expression to get:

$$
\Delta i_{j t}=c_{j}+\theta_{p} \Delta \pi_{j t}+\theta_{y} \Delta y_{j t}+\theta_{s} \Delta i_{t}^{*}+\Delta m_{t}
$$

where $c_{j}=\bar{y}_{j t}-\bar{y}_{j t-1}$. It should be noted that this specification assumes that the growth in potential is country-specific and constant across time.

This functional form leads to a panel data estimation that can be used to estimate values of the Taylor rule parameters $\theta_{p}, \theta_{y}$, and $\theta_{s}$. We consider an unbalanced panel of 129 emerging market and developing countries and 39 years of annual observations, 1973-2011, for a total of 2784 observations. These observations can be divided into 2 subgroups, based on whether the country-year observation has a floating currency or an exchange rate peg. A pegged exchange rate is one where over the course of the year, the exchange rate never varies out of a band $\pm 2 \%$ with the reference currency (the reference currency is the currency of the base country). We then estimate this equation twice, using the panel with countryyear observations where the country has a floating currency and the panel of country-year observations with a fixed currency.

The results from this estimation are presented in the first column of table 1 . Our results confirm the findings in Klein and Shambaugh (2015) and are in agreement with the trilemma. The estimated coefficient on the foreign interest rate is higher for a country with a pegged currency than for a country with a floating currency. Furthermore a country with a floating currency is able to place more weight on domestic variables like inflation.

But the results in the first column show that even for a country with a floating currency, the coefficient on the foreign interest rate is positive and significant. This itself is interesting given that the theory of the trilemma states that a country with a floating currency should have complete monetary autonomy. Of course the simple fact that a country's interest rate is correlated with world interest rate is not proof that the central bank lacks monetary policy autonomy, but in this regression we find that the central bank takes some attention away from domestic conditions like inflation and output and instead puts weight on the foreign interest rate. Furthermore, we explore the possibility that the coefficient on the foreign 
interest rate, $\theta_{s}$, may be a function of a country's level of capital account openness. To test this we consider the same regression specification, but in addition to $\Delta i_{t}^{*}$ we include the interaction between $\Delta i_{t}^{*}$ and $K_{j t}$, where $K_{j t}$ is the value of the Chinn and Ito (2008) capital account openness index in country $j$ and year $t$ (normalized on a $0-1$ scale, where 0 represents a completely closed capital account and 1 represents a completely open capital account). ${ }^{3}$

$$
\Delta i_{j t}=c_{j}+\theta_{p} \Delta \pi_{j t}+\theta_{y} \Delta y_{j t}+\theta_{s}^{c} \Delta i_{t}^{*}+\theta_{s}^{o} K_{j t} \Delta i_{t}^{*}+\Delta m_{t}
$$

where the Taylor rule coefficient on the foreign interest rate in a country with a closed capital account is $\theta_{s}^{c}$ and the coefficient in a country with an open capital account is $\theta_{s}^{c}+\theta_{s}^{o}$.

These results are presented in the second column of table 1. The same patterns seen before continue to hold, where the country with the pegged exchange rate places much more weight on the foreign interest rate and less weight on domestic inflation than the country with the floating currency. But in the results for the country with the floating currency, the coefficient on the foreign interest rate is not significantly different from zero when the country has a closed capital account, but for a country with an open capital account it is significantly positive. This suggests that capital controls have an effect on monetary policy autonomy even for a country with a floating exchange rate.

Having presented these suggestive empirical results, we will now turn to a small open economy DSGE framework to see if a model can replicate this relationship between capital controls and monetary policy autonomy in a small open economy.

\section{The Model}

Consider an infinite-horizon model of a multi-sector small open economy that features nominal price rigidities coupled with credit frictions. The source of aggregate uncertainty is shocks to the foreign interest rate. The economy is populated by a representative household,

\footnotetext{
${ }^{3}$ This capital account openness variable could potentially be an endogenous variable, since the change in a country's interest rate may lead them to change their level of capital account restrictions. But in reality, the Chinn-Ito index moves at very low frequency, so the chances of reverse causality from year-over-year change in the nominal interest rate to changes in the Chinn-Ito index are minimal.
} 
a representative entrepreneur, a final good firm, a continuum of intermediate good firms, and a central bank that sets monetary policy and capital controls policy. Financial markets are incomplete and segmented since only households have access to international credit.

In this section we will present the model and the key equilibrium conditions; the full set of first-order conditions and market-clearing conditions is available in the appendix.

\subsection{Households}

Households supply labor to the intermediate good sector and lend to entrepreneurs. They consume from their labor income, interest on savings and profits from firms, which they own. Households are risk-averse and derive utility from consumption and disutility from labor effort.

The representative household in the home country chooses consumption, $C_{t}$, labor effort, $H_{t}$, and home and foreign bond holdings, $B_{t}$ and $B_{t}^{f}$ respectively, ${ }^{4}$ to maximize expected lifetime utility given by:

$$
E_{0} \sum_{t=0}^{\infty} \beta^{t}\left[\ln \left(C_{t}\right)-\psi H_{t}^{1+\frac{1}{\sigma_{H}}}\right]
$$

with $\beta \in(0,1), \psi>0$, and the Frisch elasticity of labor $\sigma_{H}>0$.

The households' budget constraint expressed in local currency is given by:

$$
P_{t} C_{t}+B_{t}+S_{t} B_{t}^{f}=W_{t} H_{t}+\Xi_{t}+\left(1+i_{t-1}\right) B_{t-1}+\left(1-\tau_{t-1}\right)\left(1+i_{t-1}^{f}\right) S_{t} B_{t-1}^{f}+T_{t}
$$

where $P_{t}$ is the price of the final consumption good, $W_{t}$ is the nominal wage rate, $S_{t}$ is the nominal exchange rate (expressed in units of the home currency per units of foreign currency), $\Xi_{t}$ is profit from firms in the intermediate good sector, $T_{t}$ are lump-sum transfers from the government, and $i_{t}$ is the nominal interest rate on home currency bonds purchased in period $t$. The interest rate on foreign currency denominated bonds is the combination of

\footnotetext{
${ }^{4}$ Throughout the paper, bond holdings denoted with a superscript $f$ are denominated in the foreign currency while bond holdings written without it are denominated in the home currency.
} 
a exogenous foreign risk-free rate, $i_{t}^{*}$, and a debt-elastic interest premium:

$$
i_{t}^{f}=i_{t}^{*} \exp \left(-\zeta \tilde{B}_{t}^{f}\right)
$$

where $\tilde{B}_{t}^{f}$ is the aggregate debt in foreign currency bonds. The parameter $\zeta$ is positive implying that borrowing costs are increasing in the home country debt level. It ensures the stationarity of the linear approximation of this small open economy model, as in SchmittGrohe and Uribe (2003). Note that the risk premium depends on the aggregate stock of foreign currency denominated bonds across all households, so the representative household does not internalize the effect of his actions on it. Capital controls are captured by the tax rate $\tau_{t}$ that the central bank applies to holdings of foreign bonds purchased in period $t$; more detail is provided later in this section.

The total proceeds from the capital control taxes and bond adjustment costs are redistributed to the domestic households in a lump-sum fashion via $T_{t}$ :

$$
T_{t}=\tau_{t-1}\left(1+i_{t-1}^{f}\right) S_{t} \tilde{B}_{t-1}^{f}
$$

The first order condition of the household's problem with respect to consumption is:

$$
\frac{1}{C_{t}}=P_{t} \Lambda_{t}
$$

where $\Lambda_{t}$ is the multiplier on the household's budget constraint (the marginal utility of income). Consumer price inflation is given by: $\pi_{t}=\frac{P_{t}}{P_{t-1}}-1$.

The households' first order condition with respect to domestic currency bond holdings gives rise to the household's Euler equation:

$$
1+i_{t}=\frac{\Lambda_{t}}{\beta E_{t}\left(\Lambda_{t+1}\right)}
$$

Household first-order conditions for home and foreign currency bond holdings yield an un- 
covered interest parity condition:

$$
\frac{\left(1+i_{t}^{f}\right)\left(1-\tau_{t}\right) E_{t}\left(\Lambda_{t+1} S_{t+1}\right)}{S_{t}}=\left(1+i_{t}\right) E_{t}\left(\Lambda_{t+1}\right)
$$

\subsection{Entrepreneurs}

The representative entrepreneur supplies labor to firms in the intermediate goods sector. In addition, they own capital and rent it firms. They finance this stock of capital partially with their own equity and partially by borrowing in their local currency.

The representative entrepreneur in the home country chooses their consumption $C_{t}^{e}$, labor effort, $H_{t}^{e}$, investment $I_{t}$, capital stock $K_{t}$, and domestic currency bond holdings $b_{t}$, to maximize expected lifetime utility given by:

$$
E_{0} \sum_{t=0}^{\infty} \bar{\beta}^{t}\left[\ln \left(C_{t}^{e}\right)-\psi\left(H_{t}^{e}\right)^{1+\frac{1}{\sigma_{H}}}\right]
$$

subject to his budget constraint:

$$
P_{t} C_{t}^{e}+P_{t} I_{t}+b_{t}=W_{t} H_{t}^{e}+R_{t} K_{t-1}+\left(1+i_{t-1}\right) b_{t-1}
$$

where $K_{t-1}$ is his stock of capital at the beginning of the period, $R_{t}$ is the rental rate on capital, and $b_{t}$ is his asset position on one-period bonds denominated in local currency. ${ }^{5}$

The entrepreneur's discount factor is $\bar{\beta}$, which is less than the household's discount factor of $\beta$. This simply ensures that in the steady state equilibrium, entrepreneurs borrow and households save. The calibration of both of these discount factors is presented in the next section.

Capital accumulation is subject to a constant depreciation rate $\delta$ and investment adjustment costs captured by the function $F\left(I_{t}, I_{t-1}\right)$. The stock of capital then evolves according

\footnotetext{
${ }^{5}$ The restriction that home entrepreneurs cannot hold foreign currency denominated bonds in the model is intended to prevent exchange rate fluctuations from having a distortionary balance-sheet effects on entrepreneurs, as in Cespedes et al. (2004). This would give the central bank even more incentive to sacrifice monetary independence in favor of capital flow and exchange rate stability.
} 
to the following capital accumulation equation:

$$
K_{t}=(1-\delta) K_{t-1}+F\left(I_{t}, I_{t-1}\right) I_{t}
$$

where $F\left(I_{t}, I_{t-1}\right)=1-\frac{\kappa}{2}\left(\frac{I_{t}}{I_{t-1}}-1\right)^{2}$, with $\kappa>0$, as in Christiano et al. (2005).

Given this investment adjustment costs there is not a one-to-one transformation between final goods and existing capital. This ensures that the current price of existing capital relative to the price of the final good is a function of past, present and future investment decisions and the investment adjustment friction parameter, $\kappa$. In a competitive market where existing capital can be traded among entrepreneurs, the equilibrium relative price of existing capital, $P_{t}^{K}$, is given by:

$$
P_{t}=\left(1-\frac{\kappa}{2}\left(\frac{I_{t}}{I_{t-1}}-1\right)^{2}-\kappa\left(\frac{I_{t}}{I_{t-1}}-1\right) \frac{I_{t}}{I_{t-1}}\right) P_{t}^{K}+\bar{\beta} \kappa E_{t}\left[\left(\frac{I_{t+1}}{I_{t}}-1\right)\left(\frac{I_{t+1}}{I_{t}}\right)^{2} P_{t+1}^{K}\right]
$$

As in Liu et al. (2013), due to limited enforcement, entrepreneurs face an occasionally binding collateral constraint, through which they cannot borrow more than a fraction $\theta$ of the discounted expected market value of their capital stock next period:

$$
-\left(1+i_{t}\right) b_{t} \leq \theta E_{t}\left[P_{t+1}^{K}\right] K_{t}
$$

The entrepreneurs' Euler condition gives rise to the following expression linking the entrepreneurs' stochastic discount factor with the real interest rate:

$$
1+i_{t}=\frac{\Lambda_{t}^{e}}{\bar{\beta} E_{t}\left(\Lambda_{t+1}^{e}\right)+\mu_{t}}
$$

where $\Lambda_{t}^{e}$ is multiplier of the entrepreneur's budget constraint (the marginal utility of income for entrepreneurs) and $\mu_{t}$ is the Lagrange multiplier associated with the collateral constraint. When the collateral constraint binds, we observe a wedge given by $\mu_{t}\left(1+i_{t}\right)$ between the current shadow value of income and the expected one next period, reflecting the entrepreneur's limited ability to reallocate wealth to intertemporally smooth consumption. 


\subsection{Firms}

There are two types of firms, final goods firms and intermediate goods firms. Final goods firms operate in a perfectly competitive market and simply combine domestically produced and imported intermediate goods to produce a final good for consumption or investment. Intermediate goods firms are monopolistic competitors and produce a differentiated intermediate good that can be sold domestically or exported. They set prices according to a Calvo-style price setting framework.

\subsubsection{Final Goods Producers}

A finals good sector produces output in a perfectly competitive market. Each of the final goods firms combines domestic goods and imports in a CES Armington aggregator:

$$
y_{t}=\left[(\omega)^{\frac{1}{\rho}}\left[y_{t}^{d}\right]^{\frac{\rho-1}{\rho}}+(1-\omega)^{\frac{1}{\rho}}\left[y_{t}^{m}\right]^{\frac{\rho-1}{\rho}}\right]^{\frac{\rho}{\rho-1}}
$$

where the parameter $\rho$ is the Armington elasticity between the composites $y_{t}^{d}$ and $y_{t}^{m}$, and $\omega$ is the Armington weight of the former reflecting the degree of home bias in the local production. Final output is used in the home country for consumption of households and entrepreneurs and investment,

$$
y_{t}=C_{t}+C_{t}^{e}+I_{t}
$$

From this Armington aggregator function, the demand functions for domestically produced goods and imports are given by:

$$
y_{t}^{d}=\omega\left(\frac{P_{t}^{d}}{P_{t}}\right)^{-\rho} y_{t} \quad \text { and } \quad y_{t}^{m}=(1-\omega)\left(\frac{P_{t}^{m}}{P_{t}}\right)^{-\rho} y_{t}
$$

where $P_{t}^{d}$ is the price index of domestically produced goods, $P_{t}^{m}$ is the price index of imported goods, and $P_{t}$ is the consumer price index in this small open economy. The import price index is simply the price level in the rest of the world multiplied by the nominal exchange rate $P_{t}^{m}=S_{t} P_{t}^{*}$. In this small open economy model, we can assume that the price level in the rest of the world remains equal to 1 . The consumer price index is given by $P_{t}=$ 


$$
\left[\omega\left(P_{t}^{d}\right)^{1-\rho}+(1-\omega)\left(P_{t}^{m}\right)^{1-\rho}\right]^{\frac{1}{1-\rho}}
$$

\subsubsection{Intermediate Goods Producers}

The composite $y_{t}^{d}$ results from combining a continuum of domestic differentiated intermediate goods, through a Dixit-Stiglitz aggregator:

$$
y_{t}^{d}=\left(\int_{0}^{1} y_{t}^{d}(i)^{\frac{\sigma-1}{\sigma}} d i\right)^{\frac{\sigma}{\sigma-1}}
$$

where $\sigma>1$ is the elasticity of substitution across varieties. Exports from domestic intermediate goods firms are aggregated with a similar function:

$$
y_{t}^{x}=\left(\int_{0}^{1} y_{t}^{x}(i)^{\frac{\sigma-1}{\sigma}} d i\right)^{\frac{\sigma}{\sigma-1}}
$$

From these aggregator functions, the demand function for output from intermediate good firm $i$ is given by:

$$
y_{t}^{d}(i)+y_{t}^{x}(i)=\left(\frac{P_{t}(i)}{P_{t}^{d}}\right)^{-\sigma} y_{t}^{d}+\left(\frac{P_{t}(i)}{P_{t}^{x}}\right)^{-\sigma} y_{t}^{x}
$$

where $P_{t}^{d}=P_{t}^{x}=\left(\int_{0}^{1}\left(P_{t}(i)\right)^{1-\sigma} d i\right)^{\frac{1}{1-\sigma}}$. The Law of One Price holds for each variety $i$, so the price of exports from the small open economy in the rest of the world are $\frac{P_{t}^{x}}{S_{t}}$. Therefore export demand is given by:

$$
y_{t}^{x}=\left(\frac{P_{t}^{x}}{S_{t}}\right)^{-\rho} y^{x}
$$

where the constant $y^{x}$ is set to ensure that trade is balanced in the steady state, $y^{x}=$ $(1-\omega) y$, where $y$ is steady state output in the small open economy.

Intermediate good producer $i$ operates a Cobb-Douglas production function:

$$
y_{t}^{d}(i)+y_{t}^{x}(i)=h_{t}(i)^{1-\alpha} k_{t}(i)^{\alpha}
$$

where the parameter $\alpha \in(0,1)$ is the capital share, common across all varieties, $h_{t}(i)$ and 
$k_{t}(i)$ are the labor and capital employed by the intermediate good firm in period $t$.

From its cost minimization problem, the demand functions from intermediate good firm $i$ for labor and capital are given by:

$$
\begin{aligned}
h_{t}(i) & =(1-\alpha) \frac{M C_{t}}{W_{t}}\left(y_{t}^{d}(i)+y_{t}^{x}(i)\right) \\
k_{t}(i) & =\alpha \frac{M C_{t}}{R_{t}}\left(y_{t}^{d}(i)+y_{t}^{x}(i)\right)
\end{aligned}
$$

where $M C_{t}=\left(\frac{W_{t}}{1-\alpha}\right)^{1-\alpha}\left(\frac{R_{t}}{\alpha}\right)^{\alpha}$ denotes the marginal cost of production.

Market clearing in the labor and capital markets requires that the total demand for labor by firms is equal to the supply of labor from households and entrepreneurs:

$$
H_{t}+H_{t}^{e}=\int_{0}^{1} h_{t}(i) d i
$$

And the quantity of physical capital employed by firms in period $t$ is equal to the economy's stock of physical capital at the beginning of the period:

$$
K_{t-1}=\int_{0}^{1} k_{t}(i) d i
$$

GDP is simply given by final demand plus net exports, $G D P_{t}=y_{t}+y_{t}^{x}-y_{t}^{m}$.

Price setting. Firms in the intermediate good sector set prices according to a Calvo style price setting framework. In period $t$, each firm will be able to change its price with probability $1-\xi_{p}$. For each item sold to the home or the foreign market the firm receives a constant subsidy of $\nu$. This subsidy is simply introduced to offset the monopolistic competition distortion and remove this steady state inefficiency. The subsidy is financed through a lump sum tax to firms.

Thus a firm that is allowed to change its price in period $t$, will do so to maximize:

$$
\max _{P_{t}(i)} E_{t}\left[\sum_{\tau=0}^{\infty} \beta^{\tau}\left(\xi_{p}\right)^{\tau} \Lambda_{t+\tau}\left\{\left(P_{t}(i)+\nu\right)\left(y_{t+\tau}^{d}(i)+y_{t+\tau}^{x}(i)\right)-M C_{t+\tau}\left(y_{t+\tau}^{d}(i)+y_{t+\tau}^{x}(i)\right)\right\}\right]
$$


The price set optimally in period $t$ is given by:

$P_{t}(i)=\frac{\sigma}{\sigma-1} \frac{E_{t} \sum_{\tau=0}^{\infty} \beta^{\tau}\left(\xi_{p}\right)^{\tau} \Lambda_{t+\tau}\left(M C_{t+\tau}-\nu\right)\left(\omega\left(\frac{1}{P_{t+\tau}^{d}}\right)^{-\sigma}\left(\frac{P_{t+\tau}^{d}}{P_{t+\tau}}\right)^{-\rho} y_{t+\tau}+\left(\frac{1}{P_{t+\tau}^{x}}\right)^{-\sigma}\left(\frac{P_{t+\tau}^{x}}{S_{t+\tau}}\right)^{-\rho} y^{x}\right)}{E_{t} \sum_{\tau=0}^{\infty} \beta^{\tau}\left(\xi_{p}\right)^{\tau} \Lambda_{t+\tau}\left(\omega\left(\frac{1}{P_{t+\tau}^{d}}\right)^{-\sigma}\left(\frac{P_{t+\tau}^{d}}{P_{t+\tau}}\right)^{-\rho} y_{t+\tau}+\left(\frac{1}{P_{t+\tau}^{x}}\right)^{-\sigma}\left(\frac{P_{t+\tau}^{x}}{S_{t+\tau}}\right)^{-\rho} y^{x}\right)}$

If prices are flexible, i.e. $\xi_{p}=0$, then this expression collapses to:

$$
P_{t}(i)=\frac{\sigma}{\sigma-1}\left(M C_{t}-\nu\right)
$$

which implies that the firm will charge a constant mark-up over its marginal cost less the subsidy. To remove the monopolistic competition distortion in the steady state, $\nu=\frac{M C}{\sigma}$, where $M C$ is the steady state marginal cost. ${ }^{6}$

Let $\tilde{P}_{t}(i)$ denote the price chosen by firm $i$ that can reset prices in period $t$. Firms that can reset prices in period $t$ will all reset to the same level, so $\tilde{P}_{t}(i)=\tilde{P}_{t}$. By the law of large numbers, only $1-\xi_{p}$ of firms will be able to change their price in a given period, and the remaining $\xi_{p}$ firms keep their prices fixed. Thus the price index for domestic traded goods, $P_{t}^{d}$, can be written as:

$$
P_{t}^{d}=\left(\xi_{p}\left(P_{t-1}^{d}\right)^{1-\sigma}+\left(1-\xi_{p}\right)\left(\tilde{P}_{t}\right)^{1-\sigma}\right)^{\frac{1}{1-\sigma}}
$$

\subsection{Monetary and Capital Controls Policy}

Price frictions and credit frictions lead to distortions in the decentralized market allocation.

Nominal price rigidities lead to distortions in domestic production resulting from price dispersion. At the same time, due to the credit friction, the borrowing capacity of entrepreneurs is limited by the market value of their collateral. This collateral constraint gives rise to a Fisherian debt-deflation mechanism. A fall in the price of existing capital leads to a tightening of the borrowing constraint. As we discuss later in this section, this leads to a distortion

\footnotetext{
${ }^{6}$ Due to sticky output prices, the firm may earn a non-zero profit in some periods. Firm profits, given by $\Xi_{t}(i)=\left(P_{t}(i)+\nu\right)\left(y_{t}^{d}(i)+y_{t}^{x}(i)\right)-W_{t} h_{t}(i)-R_{t} k_{t}(i)-\nu\left(y_{t}^{d}+y_{t}^{x}\right)$ are returned lump-sum to the households.
} 
in the intertemporal savings/investment decisions of entrepreneurs.

To minimize the effect of these distortions, the central bank sets monetary and (potentially) capital controls policy. Monetary policy is given by an optimal simple rule for the nominal risk-free rate, as in Schmitt-Grohé and Uribe (2007). In particular, we restrict our attention to the class of policy rules with the Taylor-rule functional form in (1) where the nominal interest rate is a function of inflation, the output gap, and the foreign interest rate:

$$
i_{t}=i_{s s}+\theta_{p}\left(\pi_{t}^{d}\right)+\theta_{y}\left(\operatorname{og}_{t}\right)+\theta_{s}\left(i_{t}^{*}-i_{s s}^{*}\right)
$$

where $\pi_{t}^{d}$ is the inflation of domestically produced goods and $o g_{t}$ is the output gap - that is, $\log G D P$ minus $\log G D P$ in the frictionless economy-, and $i_{s s}$ and $i_{s s}^{*}$ are the steady state values of the home and foreign nominal interest rate, respectively. ${ }^{7}$ The frictionless economy features flexible prices, no collateral constraint, an open capital account, and the same steady state as our benchmark economy with price and credit frictions. ${ }^{8}$

Recall that the tax rate on the return from foreign bond holdings represents capital controls in the model. This is a potential policy instrument that gives the central bank the ability to control net capital inflows. Assume these tax rates take the following functional form:

$$
\tau_{t}=\chi\left(i_{t}^{f}-i_{t}\right)
$$

With this functional form, when $\chi=0$ the capital account is open. When capital controls are in place, $\chi>0$, and whenever there is a difference between the home and foreign interest rates, the central bank imposes a capital tax (or subsidy) to discourage or encourage net capital inflows.

\footnotetext{
${ }^{7}$ The results are robust to adopting other functional forms, such as including the lagged interest rate in the policy rule, and are available upon request.

${ }^{8}$ In this framework, borrowing constraints are necessary to establish the existence of a steady state. Entrepreneurs and households have different discount factors, and a comparison of the expressions for the stochastic discount factors in (4) and (10) shows that if there is no borrowing constraint and in the steady state $\mu=0$, there would be no steady state equilibrium. Therefore in the model without financial frictions, we need to impose a constant tax/subsidy on entrepreneur borrowing that encourages entrepreneurs to save and lowers their steady-state discount factor when $\mu=0$. This constant tax can be calibrated such that the frictionless economy has the same steady state as the economy with financial frictions, and this steady state tax is described in the appendix.
} 
The coefficients of the rules for the interest rate and capital tax rate are then chosen optimally to minimize the following loss function:

$$
L_{0}=\sum_{t=0}^{\infty} \beta^{t}\left(E_{0}\left(\pi_{t}^{d}-\bar{\pi}\right)^{2}+\varphi E_{0}\left(o g_{t}\right)^{2}\right)
$$

with $\varphi>0$. This loss function depends on inflation in the price index of domestically produced goods, $\pi_{t}^{d}$, not inflation in the consumer price index, $\pi_{t}$, since domestic production distortions arising from price dispersion would depend on domestic and not imported prices (see e.g. Woodford (2003)). The central bank's inflation target $\bar{\pi}$ is zero. As discussed by Woodford (2002), this is the target that would minimize the distortions arising from sticky prices in the model. ${ }^{9}$

In what follows we show how the central bank places a non-negligible weight on the foreign interest rate in its simple interest rate rule when financial frictions lead to significant distortions in the economy following a shock to the foreign rate.

Also, the exact welfare reducing distortions and the way that capital controls can reduce those distortions are described in the following subsection.

\subsubsection{Equilibrium Dynamics after Shocks to the Foreign Interest Rate}

Following a positive shock to the foreign nominal interest rate, $i_{t}^{*}$, the return on foreign currency denominated bonds increases. This exogenous shock to the foreign interest rate leads to an increase in net capital outflows. As shown in the household budget constraint (3), households will buy more foreign bonds, $B_{t}^{f}$, and substitute away from consumption and local bonds, $C_{t}$ and $B_{t}$. This fall in consumption will lead to a rise in the household's marginal utility of consumption and thus a rise in the home real interest rate, as seen by the household's Euler equation (4). As households substitute away from home consumption and local bonds to foreign bonds the home interest rate increases and at the same time, this capital outflow out of the home country causes a depreciation in the nominal exchange rate, represented by an increase in $S_{t}$ in the UIP condition (5). These two actions, an increase

\footnotetext{
${ }^{9}$ In this specification, future loss is discounted using the household's discount rate $\beta$. The results are similar when using the entrepreneur's discount rate $\bar{\beta}$.
} 
in the home nominal interest rate and exchange rate depreciation together ensure that the UIP condition holds in the new equilibrium after the shock to the foreign interest rate. ${ }^{10}$

The rise in the interest rate leads to a fall in physical capital investment. The fall in physical capital investment leads to a fall in the price of existing capital due to the presence of investment adjustment costs and the declining marginal product of physical capital investment, as shown in (8) (this declining marginal product of physical capital investment means that each new unit of final good that is allocated to physical capital investment yields less physical capital). The fall in the price of existing capital tightens the entrepreneur's borrowing constraint (9). The tightening of the borrowing constraint raises the multiplier $\mu_{t}$. The increase in the multiplier distorts the entrepreneur's intertemporal allocation decision in (10). A comparison of the household's and entrepreneur's Euler conditions (4) and (10) shows that the fact that the entrepreneur is subject to a collateral constraint leads to distortions in the entrepreneur's intertemporal allocation decision that is not present for households.

In addition to this distortion arising from the borrowing constraint in the model, there are the usual price dispersion distortions arising from the presence of nominal rigidities in the model. Of course, in a model with only price frictions, a monetary policy dedicated to price stability is optimal, as shown in Woodford (2002). A monetary policy where $\pi_{t}^{d}=0$ will reduce the value of the loss function in (15) to zero. This is true even when $\varphi>0$ and the central bank cares about output gap stability as well as inflation stability. If there were only price frictions in the model, by keeping inflation fixed at zero, monetary policy will also keep the output gap fixed at zero and allocations in the economy with sticky prices and zero inflation will mimic those of the flexible price economy. This is the meaning of the well-known "divine coincidence" result in Blanchard and Galí (2007).

The presence of both price and credit frictions in the model mean that this "divine

\footnotetext{
${ }^{10}$ How much of the adjustment to the new equilibrium is taken up by a rise in the nominal interest rate and how much is done by currency depreciation is determined by the objective of the central bank. The central bank could decide to keep the exchange rate fixed, in which case it would raise the home nominal interest rate one-for-one with the foreign nominal interest rate. Alternatively it could decide to hold the nominal interest rate fixed and allow the currency to depreciate. But in both scenarios there is a rise in the home real interest rate.
} 
coincidence" is no longer possible and perfect price stability is no longer optimal. In this case the central bank could continue to pursue a policy of price stability, but as we will show, the optimal policy of the central bank is to deviate from price stability and place some weight on reducing distortions created by the borrowing constraint. In response to the exogenous increase in the foreign nominal interest rate, the central bank can raise the home nominal interest rate, making home currency bonds more attractive and curtailing the capital outflows following the shock. In terms of the UIP condition, by raising the home nominal interest rate following the shock, equilibrium can be restored without as much currency depreciation (and thus without as much capital outflow).

Capital controls, in the form of the tax rate on foreign bond holdings $\tau_{t}$, can mitigate the swings in capital outflows following the shock to the foreign interest rate. When $\chi$ is positive in the functional form for the capital control tax in (14), the tax rate on foreign bond holdings will increase following as an exogenous increase in $i_{t}^{f}$. Since the return on those bonds is $\left(1-\tau_{t}\right)\left(1+i_{t}^{f}\right)$, following an exogenous increase in $i_{t}^{f}$ an increase in $\tau_{t}$ reduces household incentive to substitute away from home currency bonds to foreign currency bonds. The return to foreign currency bonds net of this capital tax $\left(1-\tau_{t}\right)\left(1+i_{t}^{f}\right) \approx 1+(1-\chi) i_{t}^{f}+\chi i_{t}$. As $\chi$ increases, the effect of the exogenous shock on the desire to hold foreign bonds diminishes, and when $\chi=1$, the exchange rate is nearly fixed. ${ }^{11}$ By using capital taxes to control swings in capital flows following the shock, the central bank can limit the swings in the price of capital that lead to tightening or loosening of the borrowing constraint. Thus with capital controls, the central bank can largely mitigate the effect of distortions arising from credit frictions. With these credit frictions taken care of by a second instrument, the conditions for the divine coincidence return and the central bank can once again minimize loss by following a policy of price stability.

But at the same time these capital controls are not costless. Taxes on the returns to foreign borrowing limit the ability of agents to borrow and lend in international markets to smooth consumption. When determining the optimal value of the parameter $\chi$ the central

\footnotetext{
${ }^{11}$ Thus $\chi=1$ marks the point on the trilemma of international finance where the central bank has a fixed exchange rate and an independent monetary policy.
} 
bank balances these costs against the benefits of capital controls in terms of reduced credit distortions and monetary policy more focused on price stability.

\section{Calibration and Solution Method}

The model is calibrated at a quarterly frequency. The model parameters and their values are reported in table 2 . The first seven parameters in the table, the time discount factor, the capital share, the capital depreciation rate, the investment adjustment cost parameter, the probability that a firm cannot reset prices in a given period, and the elasticities of substitution across differentiated intermediate goods, and between home and foreign traded goods, are all set to values commonly used in the literature. The debt elastic interest premium on foreign bonds $\zeta$ affects the volatility of net exports; it is calibrated such that the ratio of net exports to GDP is about two-thirds as volatile as GDP, as reported in Engel and Wang (2011). The weight on domestic goods in the Armington aggregator function, $\omega$ is set to match a steady state import share of 50 percent. The parameter $\varphi$ describes the weight on the output gap in the central bank's loss function and it set to 0.1 .

The difference between the values of the household and entrepreneur discount factors, $\beta$ and $\bar{\beta}$, implies that the first-order excess return is about 3.6 percent per year. ${ }^{12}$

The parameter $\theta$ controls the entrepreneur's steady-state loan-to-value ratio. We use a value of 0.75 , which is the value used by Liu et al. (2013). In a model with collateral constraints for multiple types of agents, Iacoviello (2005) estimates this parameter and finds that it lies between 0.55 (for households) and 0.89 (for firms).

We will just consider the effect of shocks originating in the rest of the world on the small open home economy. More specifically, we analyze the optimal policy response to a shock to the foreign interest rate that would lead to a surge in capital flows into or out of the small open economy.

\footnotetext{
${ }^{12}$ In the non-stochastic steady state, the risk-free rate $r$ is $r=\frac{1}{\beta}-1$, which reflects the household's discount rate, $\beta$. The steady-state net return on capital, $R-\delta=\frac{1}{\bar{\beta}}-1$, reflects the entrepreneur's discount rate $\bar{\beta}$. The per annum steady-state first-order excess return is then given by $(1+R-\delta-r)^{4}-1=\left(1+\frac{1}{\beta}-\frac{1}{\beta}\right)^{4}-1 \approx$ $4(\beta-\bar{\beta})$.
} 
To calibrate the process for the foreign interest rate shock, we estimate an $\operatorname{AR}(1)$ process for the quarter-over-quarter difference in the U.S. 3-month Treasury bill rates from 1984:Q1 to 2008:Q4:

$$
\hat{\imath}_{t}^{*}=\rho_{i} \hat{\imath}_{t-1}^{*}+\varepsilon_{t}^{*}
$$

where $\varepsilon_{t}^{*} \sim N\left(0, \sigma_{\varepsilon^{*}}^{2}\right)$. The OLS estimates are $\hat{\rho}_{i}=0.59$ and $\hat{\sigma}_{\varepsilon^{*}}=0.1 .^{13}$

\subsection{Solution Procedure}

The model is solved by taking a linear approximation of the system's equilibrium conditions around the non-stochastic steady state. But at the same time we use a piecewise linear technique to approximate a non-linear solution to account for the occasionally binding collateral constraint. Thus we abstract from all nonlinearities in the model except that of the occasionally binding collateral constraint.

In the non-stochastic steady state, the collateral constraint binds, and a comparison of the household and entrepreneur Euler equations in (4) and (10) shows that the steady-state value of the Lagrange multiplier of the borrowing constraint, $\mu$, divided by the steady-state value of the entrepreneur's marginal utility of income is equal to the difference between household and entrepreneur's rates of time discounting. ${ }^{14}$ In the benchmark version of the model without capital controls, a 21 basis point fall in the foreign nominal interest rate would cause a surge in capital inflows into the small open economy that would push up asset prices to the point where the constraint is no longer binding and $\mu_{t}=0$. Given the calibration of the shock process driving the model, this would roughly be a two standard deviation shock to the foreign interest rate.

To solve the model and account for the occasionally binding constraint, we adapt the method that Bodenstein et al. (2013) use to study the effect of the zero lower bound to nominal interest rates. This is based on the method of introducing news shocks into a

\footnotetext{
${ }^{13}$ The innovation standard deviation is 10 basis points for the quarterly rates in the model, which corresponds to 40 basis points in annualized rates.

${ }^{14}$ From the household and entrepreneur Euler equations (4) and (10): $\frac{\Lambda_{t}^{e}}{\bar{\beta} E_{t}\left(\Lambda_{t+1}^{e}\right)+\mu_{t}}=\left(1+i_{t}\right)=\frac{\Lambda_{t}}{\beta E_{t}\left(\Lambda_{t+1}\right)}$. So in the steady state, $\beta-\bar{\beta}=\frac{\mu}{\Lambda^{e}}$.
} 
first-order approximation developed by Laséen and Svensson (2009), and then developed into a framework for approximating the solution to non-linear models by Holden and Paetz $(2012) \cdot{ }^{15}$

Here we adapt this method to study the effect of a non-binding collateral constraint, and this is described in detail in the appendix. When presenting impulse response results, we will present the results to both a positive shock to the foreign interest rate which tightens the collateral constraint and to a negative shock that loosens the constraint to the point where it is non-binding. Optimal policy responses are not symmetric, although we will show that they are very similar.

\section{Optimal Monetary and Capital Controls Policy}

In analyzing optimal capital account management, we present the results in three steps. First, we consider impulse responses, which let us examine how the use of capital controls affects the conduct of conventional monetary policy. Here monetary policy is chosen with an optimal simple rule, and with this simple rule optimal policy we can show how when credit frictions are present the central bank places a sizable weight on the foreign interest rate in their policy rule and the use of capital controls allows them to reduce this weight. Finally, we will look at measures of household and entrepreneur welfare losses under different monetary and capital controls policy regimes to better gauge the costs and potential benefits of these policies.

\section{$5.1 \quad$ Impulse Responses}

The responses of home output, investment, inflation, credit constraints (measured by the multiplier on the collateral constraint), the tax on capital flows, the nominal interest rate, the current account to GDP ratio (net capital outflows), and asset prices following a 50 basis point increase in the foreign nominal interest rate are presented in figure 1 . The vertical

\footnotetext{
${ }^{15}$ As described by Guerrieri and Iacoviello (2015), in several frameworks this method yields the same path for endogenous variables as the OccBin piecewise linear algorithm. We adapted Bodenstein et. al approach instead of OccBin simply for convenience reasons when coding up the model.
} 
axis in the plots for output, investment, and the price of capital are percentage deviations from the steady state values. The vertical axis in the plots for inflation, capital taxes, the nominal interest rate, and the current account to GDP ratio are percentage points. Finally, the plot of the multiplier on the borrowing constraint is in levels.

The figure presents the responses from the frictionless model (the blue dotted line), and the model with both price and credit frictions under three policy regimes: price level stability with an open capital account (the purple dashed line), optimal monetary policy with an open capital account (the red solid line), and optimal monetary policy with capital taxes of the form described in (14) where the parameter $\chi$ is also chosen optimally (the green starred line). The value of the $\chi$ parameter that would minimize the central bank's loss function is 0.5 .

The positive shock to the foreign interest rate triggers an increase in net capital outflows from the small open economy, and the figure shows that in the frictionless equilibrium there is an increase in the current account in the small open economy. In the frictionless economy we observe a slight decrease in asset prices, investment, and output.

If price frictions were the only source of distortion in the model, then a monetary policy of domestic price stability would reproduce the allocations of the frictionless equilibrium, as shown in Woodford (2002) and the well-known "divine coincidence" result in Blanchard and Galí (2007). But when credit frictions are also included in the model, limiting entrepreneur borrowing and giving rise to a Fisherian debt-deflation mechanism, this divine coincidence is no longer possible and a policy of price level stability amplifies the negative responses of investment and demand that are seen in the frictionless equilibrium. The fall in the price of physical capital following the decrease in net capital inflows leads to a tightening of the collateral constraint. The credit friction leads to a further decline in investment and output, which leads to an even further fall in asset prices. Thus when the capital account is open and monetary policy is dedicated to domestic price stability, this feedback loop caused by falling asset prices and a tightening credit constraint amplifies the contraction of domestic macro variables following the shock to the foreign interest rate.

In the presence of a second source of distortion arising from credit frictions, price level 
stability is no longer optimal. In this case the monetary policy that minimizes the central bank's loss function can be solved for numerically and is plotted with the red solid line. When responding to a shock to the foreign interest rate under optimal policy and an open capital account, the central bank will partially track the foreign interest rate with its nominal rate. By raising the domestic interest rate, it would curtail the capital outflows from the small open economy. As shown in the impulse responses, by doing this the central bank arrests some of this feedback loop where capital outflows lead to falling asset prices and tightening borrowing constraints. The responses of investment and output in the optimal monetary policy case are much closer to the responses in the frictionless equilibrium.

But the figure also shows that this policy leads to more inflation variability, as the central bank lessens its focus on price stability, it leans more toward tempering capital flows and minimizing financial instability. The shock to the foreign interest rate leads to exchange rate depreciation, which leads to an increase in import and consumer prices. If the central bank followed a policy of price stability, it would raise the nominal interest rate to keep that increase in import prices from passing through into domestic inflation. But doing this leads to a greater fall in output, investment, and asset prices. Under optimal policy the central bank will allow more inflation in order to stabilize output. These results are in line with the findings in Fornaro (2015), who studies exchange rate policy in a small open economy with nominal wage rigidities and collateral constraint. In that model, the central bank finds it optimal to deviate from price stability by engineering an exchange rate depreciation in order to sustain aggregate demand and asset prices.

When capital controls are used in addition to optimal monetary policy, the central bank can return its focus to price stability. In this case following the exogenous increase in the foreign interest rate, taxes on foreign returns increase, discouraging capital outflows. This means that the central bank does not need to raise the interest rate along side the foreign interest rate in order to deter capital outflows. The UIP condition (5) shows that when $\tau_{t}$ increases following an increase in the foreign interest rate, equilibrium can be restored without an increase in the local nominal interest rate or a depreciation of the exchange rate. The impulse responses show that for most variables, the responses under optimal monetary 
policy and an open capital account are similar to those for optimal monetary policy and capital controls, except the responses for inflation. By allowing the central bank to not worry about capital flows and instead return it's focus to price stability, the policy regime of optimal monetary policy and capital controls delivers much more stable responses of domestic inflation.

Figure 2 plots the responses of the same variables to a 50 basis point negative shock to the foreign interest rate. As discussed earlier, when this shock is sufficiently large, it will push up asset prices to the point where the collateral constraint becomes slack and remains so for some periods. As discussed earlier, we use a piecewise linear approximation of a full non-linear solution to solve the model given this asymmetry. Given a sufficiently large shock, the multiplier on the borrowing constraint falls to zero for a few periods. The responses of the other variables in the model are similar, but not identical, to the case where the constraint is always binding. The collateral constraint still leads to a greater response

in these endogenous variables than would have occurred under in a frictionless model, and a monetary policy that deviates from domestic price stability still temper the responses of these variables and bring the economy with a collateral constraint closer to the frictionless economy. The use of capital controls along side optimal monetary policy allows the central bank to stabilize output with greater inflation stabilization.

\subsection{Describing Optimal Monetary Policy}

As discussed earlier, we assume that monetary policy follows a Taylor rule with coefficients chosen to minimize the central bank's loss function (15). By looking at these response coefficients, we can examine how the use of capital controls affects the optimal rule for the conventional monetary policy instrument.

The optimal coefficients in the Taylor rule are reported in table 3. The table shows that when the capital account is open, $\chi=0$, the optimal weight on the foreign interest rate is 0.22 , implying that the central bank reduces its focus on price stability and finds it optimal to raise the nominal interest rate by 22 basis points in response to a 100 basis point 
increase in the foreign interest rate. When the $\chi$ parameter is optimally set, and $\chi=0.5$, this coefficient falls to 0.10. In addition, when capital controls are used, the central bank is able to increase its weight on inflation from 5.26 to 8.34 , implying a shift towards price stability. Recall that in the case where there are only price frictions in the model, optimal policy is price stability, where $\theta_{p} \rightarrow \infty$.

The response coefficient on the foreign interest rate is plotted as a function of the $\chi$ parameter in the capital controls rule (14) in the top panel of figure 3. The figure shows that as $\chi$ increases, the coefficient on the foreign interest rate in the central bank's monetary policy rule decreases. As it can be seen there, as $\chi$ increases from 0 to 1 , the optimal coefficient on the foreign interest rate falls from 0.22 to -0.02 .

Recall from the empirical results in table 1 that when the capital account is open, $K=1$, the estimated Taylor rule coefficient on the foreign interest rate is 0.26 and when the capital account is closed, $K=0$, it is -0.02 .

\subsection{Welfare Analysis}

In what follows we evaluate the effect of capital controls on the relative welfare losses of both households and entrepreneurs. After solving for the equilibrium under optimal monetary policy for a given value of the capital controls parameter $\chi$, we can use the equilibrium paths of household and entrepreneur's consumption and labor effort, and inflation, to calculate the effect of distortions arising from price and credit frictions on household and entrepreneur's welfare given by (2) and (6).

The household and entrepreneur's welfare loss under two different monetary policy regimes, optimal policy and price level stability, are presented in the bottom two panels in figure 3. The vertical axis in these two figure measures the difference between household or entrepreneur's welfare in the frictionless equilibrium and the equilibrium with distortions arising from price and credit frictions, as a percent of steady-state consumption. The top figure presents the welfare loss when monetary policy is chosen optimally while the bottom figure shows the results when monetary policy is dedicated to price stability. The horizontal axis 
in these figures is the capital controls parameter $\chi$, which is taken as given by private agents.

First, comparing the losses of the two types of agents in the case of an open capital account, $\chi=0$, shows how all agents are affected by a switch from monetary policy based on price stability to optimal monetary policy. Entrepreneurs see a sizable reduction in their welfare loss when monetary policy diverts its focus from domestic price stability and instead puts some weight on the foreign interest rate in an effort to control capital flows. They are most affected by the credit frictions, which leads to distortions in their intertemporal savings/consumption decision. Hence, a monetary policy that attempts to control capital flows and limit these distortions will benefit them.

As the capital control parameter $\chi$, increases from zero, entrepreneur's welfare loss falls but the variation in household's welfare loss is ambiguous and depends on monetary policy. Capital controls are not costless and they limit the ability to smooth consumption by borrowing and lending in international markets. When monetary policy is dedicated to price stability, and thus the stance of monetary policy does not change as $\chi$ increases, the adoption of capital controls leads to higher household's welfare loss. But when monetary policy is set optimally, the addition of capital controls actually leads to a change in the stance of monetary policy towards price stability. So even while households dislike capital controls that limit their ability to smooth consumption, they benefit from the fact that capital controls lead to a changed stance of monetary policy. This means that when monetary policy is set optimally, the optimal value of the capital controls parameter from the household's perspective is $\chi=0.24$, which is lower than the $\chi=0.67$ favored by entrepreneurs, or the $\chi=0.5$ that would minimize total welfare loss, but still greater than the $\chi=0$ favored by households when monetary policy is dedicated to price stability, and thus an increase in $\chi$ does not lead to any change in the stance of monetary policy.

\section{Conclusion}

This paper analyzes the interaction of the capital account management with optimal monetary policy in the context of a small open economy. In the presence of occasionally binding 
collateral constraints, monetary policy will find it optimal to place a non-negligible weight on the foreign interest rate in their policy rule, and thus deviate from a monetary policy dedicated to domestic goals like price stability. Capital controls help restore monetary policy autonomy.

Focusing on a small open economy is a convenient starting point for this analysis since the dynamics associated with the rest of the world are taken as given, regardless of the policy actions in the home country. We see this assumption appropriate for most emerging economies. Extending the setup to a pair of large countries is the next step. First, when the foreign economy is affected by the policy actions in the home economy, the degree of policy coordination becomes an interesting question to study. Would the two countries cooperate when setting monetary and capital controls policy, or would they compete? This is especially relevant for studying capital controls, since capital controls policy, like tariff policy, can be seen as a beggar-thy-neighbor policy and subject to escalation. Would there be substantial benefits for countries from cooperation when setting monetary and capital control policy? Second, in the setup with two large economies, asymmetries in the strength of credit frictions between them could have an effect on their optimal capital policies, as the intensity of credit frictions may influence the central bank's desirability to manage the capital account.

While in our model non-trivial capital controls are optimal in order to restore monetary policy autonomy and to mitigate the effects of collateral constraints and fluctuations in net capital inflows, capital controls are only part of a wider set of macroprudential policies. Some studies show how capital controls and domestic macroprudential regulations can acts as complements (see e.g. Korinek and Sandri (2014)). Empirically we see a connection between capital controls and monetary policy autonomy, which can be measured by using the relatively long time series of the Chinn-Ito index measuring capital restrictions. Whether such a relationship with more general macroprudential policies exists, and how it could be measured, is left for future research. 


\section{References}

Aoki, K., Benigno, G., Kiyotaki, N., 2016. Monetary and financial policies in emerging markets. mimeo.

Benigno, G., Chen, H., Otrok, C., Rebucci, A., Young, E. R., January 2013. Capital controls or real exchange rate policy? a pecuniary externality perspective. mimeo.

Bianchi, J., 2011. Overborrowing and systemic externalities in the business cycle. American Economic Review 101 (7), 3400-3426.

Bianchi, J., Mendoza, E. G., 2015. Optimal time-consistent macroprudential policy. NBER Working Paper No. 19704.

Blanchard, O., Galí, J., 2007. Real wage rigidities and the new keynesian model. Journal of Money, Credit and Banking 39 (s1), 35-65.

Bodenstein, M., Guerrieri, L., Gust, C. J., 2013. Oil shocks and the zero bound on nominal interest rates. Journal of International Money and Finance 32, 941-967.

Brunnermeier, M. K., Sannikov, Y., 2015. International credit flows and pecuniary externalities. American Economic Journal: Macroeconomics 7 (1), 297-338.

Cespedes, L. F., Chang, R., Velasco, A., 2004. Balance sheets and exchange rate policy. American Economic Review 94 (4), 1183-1193.

Chinn, M. D., Ito, H., 2008. A new measure of financial openness. Journal of comparative policy analysis $10(3), 309-322$.

Christiano, L. J., Eichenbaum, M., Evans, C. L., 2005. Nominal rigities and the dynamic effects of a shock to monetary policy. Journal of Political Economy 113, 1-45.

Costinot, A., Lorenzoni, G., Werning, I., December 2011. A theory of capital controls and dynamic terms-of-trade manipulation. NBER Working Paper No. 17680.

De Paoli, B., Lipinska, A., February 2013. Capital controls: A normative analysis. FRBNY Staff Report No. 600.

Engel, C., February 2015. Macroprudential policy in a world of high capital mobility: Policy implications from an academic perspective. NBER Working Paper No. 20951.

Engel, C., Wang, J., 2011. International trade in durable goods: Understanding volatility, cyclicality, and elasticities. Journal of International Economics 83, 37-52.

Farhi, E., Werning, I., July 2012. Dealing with the trilemma: Optimal capital controls with fixed exchange rates. NBER Working Paper No. 18280.

Farhi, E., Werning, I., 2014. Dilemma not trilemma?; capital controls and exchange rates with volatile capital flows. IMF Economic Review 62 (4), 569-605.

Forbes, K., Warnock, F. E., 2012. Capital flow waves: Surges, stops, flight, and retrenchment. Journal of International Economics 88, 235-251. 
Fornaro, L., 2015. Financial crises and exchange rate policy. Journal of International Economics 95 (2), 202-215.

Guerrieri, L., Iacoviello, M., 2015. Occbin: A toolkit for solving dynamic models with occasionally binding constraints easily. Journal of Monetary Economics 70, 22-38.

Heathcote, J., Perri, C. F., 2016. On the desirability of capital controls. NBER Working Paper 21898.

Holden, T., Paetz, M., 2012. Efficient simulation of dsge models with inequality constraints. School of Economics Discussion Papers, University of Surrey 1612.

Iacoviello, M., 2005. House prices, borrowing constraints, and monetary policy in the business cycle. American Economic Review 95 (3), 739-764.

Jeanne, O., Korinek, A., 2010. Excessive volatility in capital flows: A pigouvian taxation approach. American Economic Review (Papers and Proceedings) 100 (2), 403-407.

Kaminsky, G. L., Reinhart, C. M., Végh, C. A., 2005. When it rains, it pours: procyclical capital flows and macroeconomic policies. In: NBER Macroeconomics Annual 2004, Volume 19. MIT Press, pp. 11-82.

Klein, M. W., Shambaugh, J. C., 2015. Rounding the corners of the policy trilemma: Sources of monetary policy autonomy. American Economic Journal: Macroeconomics 7 (4), 33-66.

Korinek, A., December 2010. Regulating capital flows to emerging markets: An externality view. mimeo.

Korinek, A., December 2013. Capital account intervention and currency wars. mimeo.

Korinek, A., Sandri, D., 2014. Capital controls or macroprudential regulation? NBER Working Paper No. 20805.

Laséen, S., Svensson, L. E., 2009. Anticipated alternative instrument-rate paths in policy simulations. NBER Working Paper No. 14902.

Liu, Z., Wang, P., Zha, T., 2013. Land price dynamics and macroeconomic fluctuations. Econometrica 81 (3), 1147-1184.

Mundell, R. A., 1963. Capital mobility and stabilization policy under fixed and flexible exchange rates. Canadian Journal of Economics and Political Science 29 (4), 475-485.

Obstfeld, M., 2015. Trilemmas and trade-offs: living with financial globalisation.

Obstfeld, M., Shambaugh, J. C., Taylor, A. M., 2005. The trilemma in history: tradeoffs among exchange rates, monetary policies, and capital mobility. Review of Economics and Statistics 87 (3), 423-438.

Reinhart, C., Reinhart, V., 2009. Capital flow bonanzas: An encompassing view of the past and present. NBER International Seminar on Macroeconomics 2008, 9-62.

Rey, H., 2015. Dilemma not trilemma: The global financial cycle and monetary policy independence. NBER Working Paper No. 21162. 
Schmitt-Grohe, S., Uribe, M., 2003. Closing small open economy models. Journal of International Economics 61, 163-185.

Schmitt-Grohé, S., Uribe, M., 2007. Optimal simple and implementable monetary and fiscal rules. Journal of monetary Economics 54 (6), 1702-1725.

Schmitt-Grohe, S., Uribe, M., 2012a. Managing currency pegs. American Economic Review (Papers and Proceedings) 102, 192-197.

Schmitt-Grohe, S., Uribe, M., May 2012b. Prudential policy for peggers. NBER Working Paper No. 18031.

Shambaugh, J. C., 2004. The effect of fixed exchange rates on monetary policy. The Quarterly Journal of Economics 119 (1), 301-352.

Woodford, M., 2002. Inflation stabilization and welfare. Contributions in Macroeconomics $2(1)$.

Woodford, M., 2003. Interest and Prices: Foundations of a Theory of Monetary Policy. Princeton University Press, Princeton, New Jersey. 
Table 1: Coefficient from regression of a country's policy rate on a base country policy rate for different subgroups depending on exchange rate flexibility and capital account openness.

\begin{tabular}{|c|c|c|c|}
\hline \multirow{3}{*}{ Peg } & & $\Delta i_{i}$ & $\Delta i_{i}$ \\
\hline & $\Delta \pi_{t}$ & $1.113^{*} \quad(0.629)$ & $1.262^{* *} \quad(0.619)$ \\
\hline & $\Delta y_{t}$ & $0.327 \quad(0.389)$ & $0.208 \quad(0.383)$ \\
\hline \multirow{10}{*}{ Float } & $\Delta i_{t}^{*}$ & $0.497^{* * *} \quad(0.030)$ & $0.231^{* * *} \quad(0.051)$ \\
\hline & $K_{t} \times \Delta i_{t}^{*}$ & & $0.583^{* * *} \quad(0.092)$ \\
\hline & Obs. & 1188 & 1188 \\
\hline & $\bar{R}^{2}$ & 0.299 & 0.324 \\
\hline & $\Delta \pi_{t}$ & $5.253^{* * *} \quad(0.788)$ & $5.326^{* * *} \quad(0.788)$ \\
\hline & $\Delta y_{t}$ & $-0.516 \quad(0.578)$ & $-0.526 \quad(0.578)$ \\
\hline & $\Delta i_{t}^{*}$ & $0.117^{* * *} \quad(0.045)$ & $-0.022 \quad(0.079)$ \\
\hline & $K_{t} \times \Delta i_{t}^{*}$ & & $0.279^{* *} \quad(0.130)$ \\
\hline & Obs. & 1596 & 1596 \\
\hline & $\bar{R}^{2}$ & 0.078 & 0.081 \\
\hline
\end{tabular}

notes: Standard errors are in parenthesis, the adj. R-squared from each regression is presented in brackets, and the integer in each set of results is the number of observations. $* * * / * * / *$ denote significance at the $1 / 5 / 10 \%$ levels.

Table 2: Parameter Values

\begin{tabular}{ccl}
\hline \hline Symbol & Value & Description \\
\hline$\beta$ & 0.9887 & household discount factor \\
$\alpha$ & 0.36 & capital share in production of value added \\
$\delta$ & 0.025 & capital depreciation rate \\
$\kappa$ & 2.48 & investment adjustment cost parameter \\
$\xi_{p}$ & 0.75 & probability that a firm cannot reset prices \\
$\sigma$ & 10 & elasticity of substitution across firm varieties \\
$\rho$ & 3 & Armington elasticity \\
$\zeta$ & 0.015 & debt elastic interest premium \\
$\omega$ & 0.50 & Armington weight on domestic goods \\
$\varphi$ & 0.1 & Weight on the output gap in the loss function \\
$\bar{\beta}$ & 0.98 & entrepreneur discount factor \\
$\theta$ & 0.75 & borrowing limit \\
\hline \hline
\end{tabular}



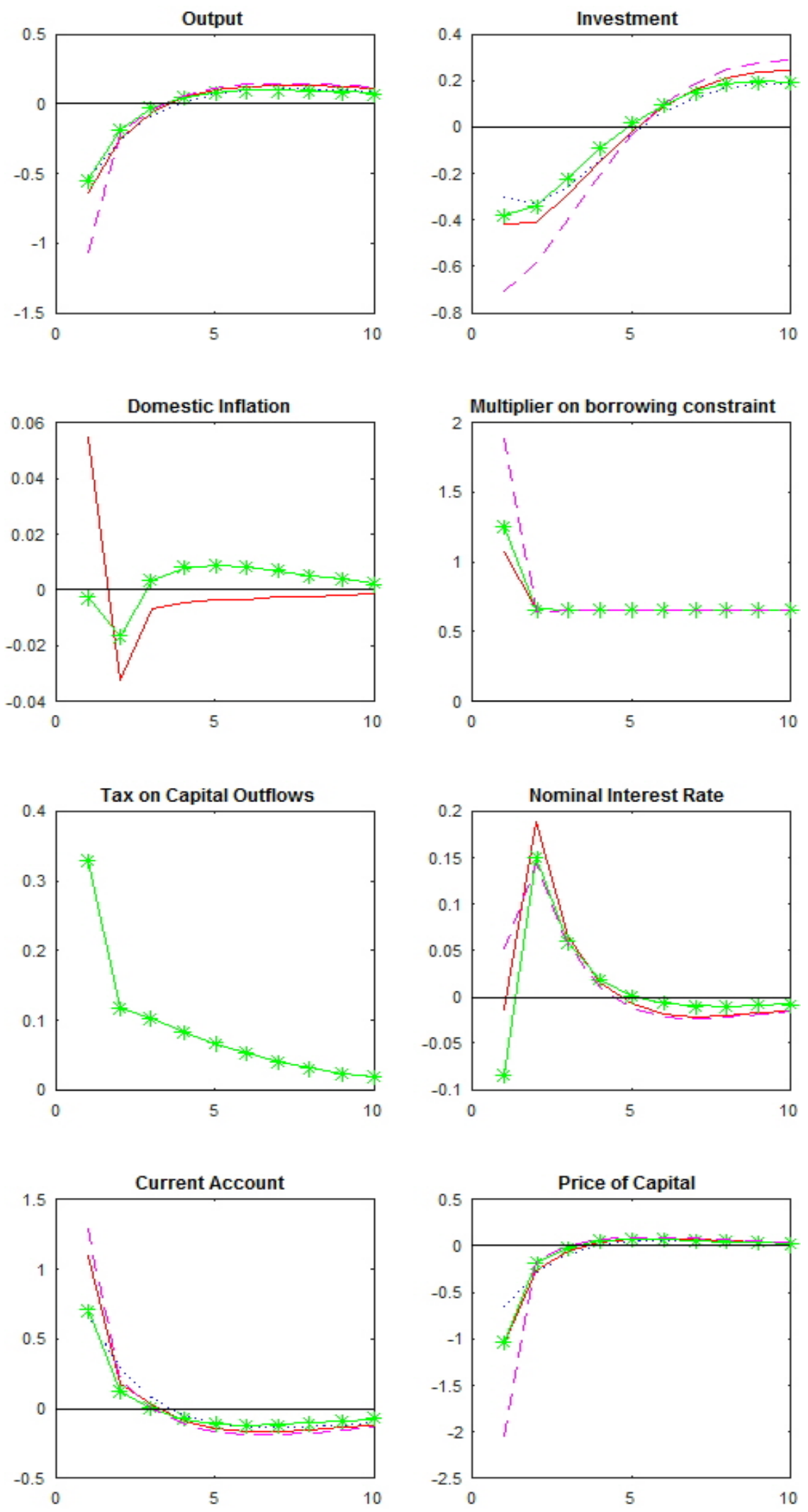

Figure 1: Responses to a positive shock to the foreign interest rate in frictionless model (blue dotted line) and in different versions of the model with price and credit frictions: price stability and an open capital account (purple dashed line), optimal monetary policy and an open capital account (red solid line), or optimal monetary policy and capital controls (green starred line). 

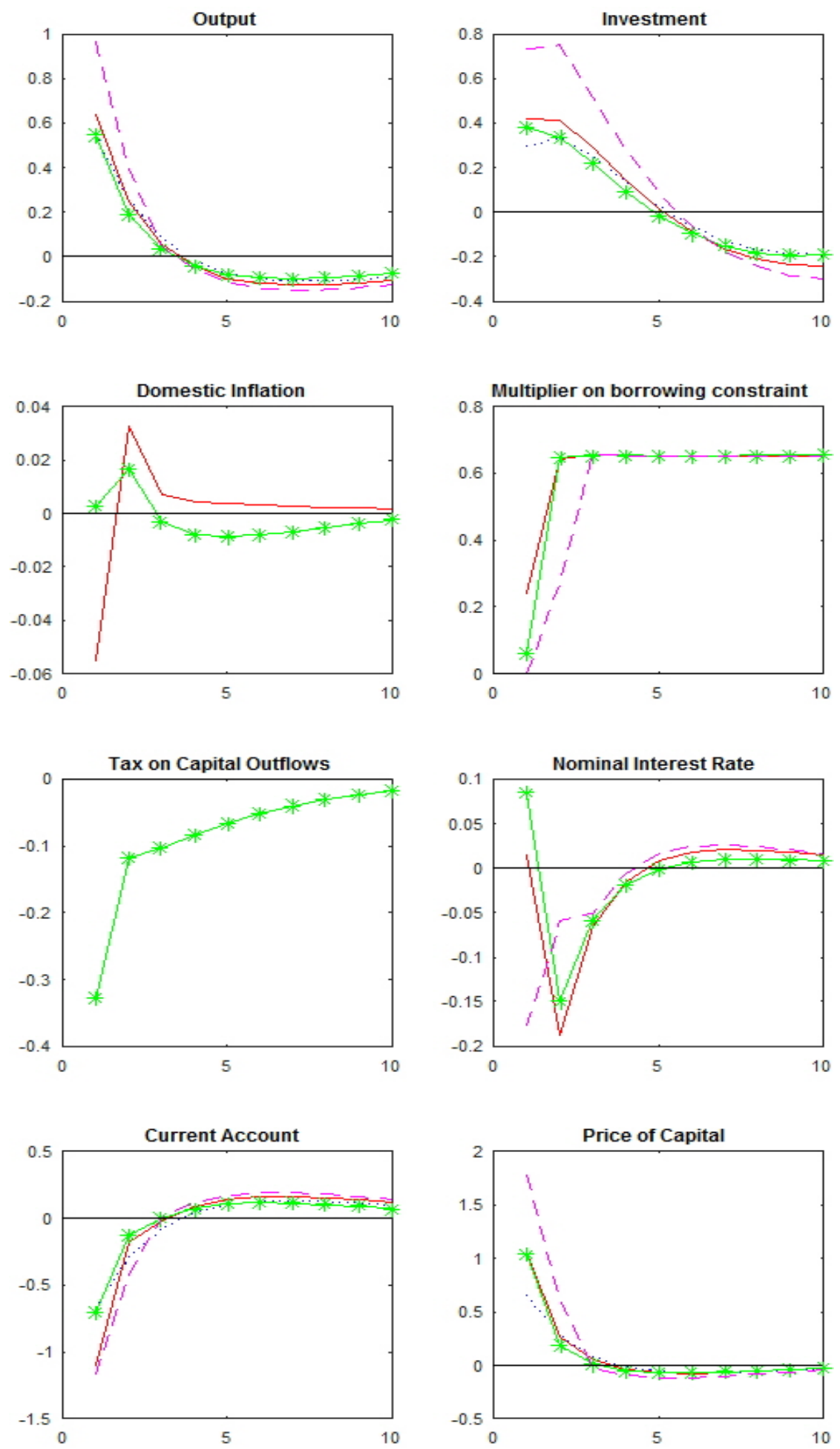

Figure 2: Responses to a negative shock to the foreign interest rate in frictionless model (blue dotted line), and in different versions of the model with price and credit frictions: price stability and an open capital account (purple dashed line), optimal monetary policy and an open capital account (red solid line), or optimal monetary policy and capital controls (green starred line) 

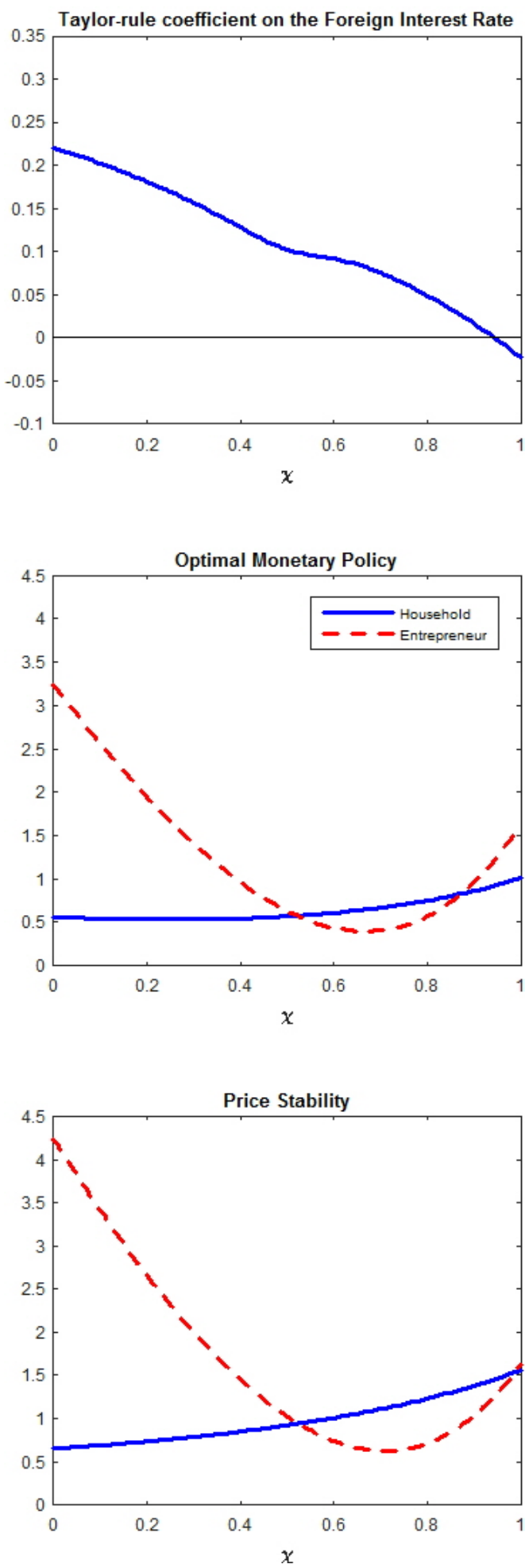

Figure 3: The Taylor rule coefficient on the foreign interest rate (from projections of numerical optimal policy onto a Taylor rule) and household and entrepreneur welfare loss as a function of the capital tax coefficient $\chi$. 
Table 3: Optimal Taylor rule coefficients in the model with and without capital controls

\begin{tabular}{|c|c|c|}
\hline & $\begin{array}{c}\text { Open Capital Account } \\
\chi=0\end{array}$ & $\begin{array}{c}\text { Optimal Capital Controls } \\
\chi \chi=0.5\end{array}$ \\
\hline & 5.26 & 8.34 \\
\hline $\mathrm{W}$ & 0.21 & 0.08 \\
\hline Weight on the foreign interest rate, $\theta_{s}$ & 0.22 & 0.10 \\
\hline
\end{tabular}

